\title{
The modern phase of the polysilicon market
}

\author{
Arkady V. Naumov ${ }^{1}$, Dmitry L. Orehov ${ }^{2}$ \\ 1 Astrohn Technology Ltd., 1 Parkovaya Str., Lytkarino, Moscow Region 140080, Russia \\ 2 Research and Development Center for Thin-Film Technologies in Energetics, 28 Politekhnicheskaya Str., St. Petersburg 194021, Russia \\ Corresponding author: Arkady V. Naumov (naumov_arkadii@mail.ru)
}

Received 3 December 2021 • Accepted 23 December 2021 • Published 30 December 2021

Citation: Naumov AV, Orehov DL (2021) The modern phase of the polysilicon market. Modern Electronic Materials 7(4): 115-126. https://doi.org/10.3897/j.moem.7.4.81721

\begin{abstract}
The current condition and outlooks of the world semiconductor and polycrystalline silicon (poly-Si) markets have been analyzed. A long period of low PS prices which hindered the growth of investments into the industry has now changed for price recovery to an investment attractive level. Demand and offer balance for the period until 2024 and for the long term has been analyzed, and the main currently used PS processes have been reviewed. The current poly-Si market proficiency is expected to remain in the near and medium terms. However the "green turn" of the energy industry announced by all the governments, the development of local markets and the price recovery to an investment attractive level have promoted the development of new PS fab projects. Of special importance for Russia is the choice of Siemens trichlorosilane process parameters. A specific feature of the Russian market is the presence of several very important fields (solar energy, microelectronics, high-power electronics, photonics and fiber optics) which are small by international standards and equally face raw material shortage. It appears that Russia will greatly benefit from integral projects delivering solutions of multiple raw materials supply problems.
\end{abstract}

\section{Keywords}

solar energy, polycrystalline silicon, overproduction, Siemens process, fluidized bed process, demand, offer, balance, price, pricing.

\section{Introduction}

This work is a continuation of our earlier study [1] dealing with the development of international markets of semiconductor polycrystalline silicon (poly-Si or polysilicon (PS)). Over the recent 15 years this industry has demonstrated uniquely high growth rates, from 20 tpy to over 500 tpy. And in the recent 5-7 years the poly-Si offer has been stably exceeding the demand, leading to a period of quite low PS prices. It was assumed [1] that this period should come to an end as the prices grow to an investment attractive level, and market estimates were made on the basis of the "project internal return rate". But as ever the real life proved to beat all predictions. We nevertheless believe that the poly-Si market is about to enter a new development phase, so important for local emerging markets including the Russian one.

\section{Raw material: technical grade silicon}

Technical (metallurgical) grade silicon is produced in an amount of more than $3 \mathrm{mln}$ tpy and used as charge for aluminum (silumines) and magnesium alloys. In the chemical industry silicon (organic silicon) processes for use in the production of plastics, paints and varnishes, lubricants etc. are currently developed. The top metallurgical grade silicon producer is China whose world market 
share is $64 \%$, followed by the US and Western Europe. The main metallurgical grade silicon consuming branch is the production of alloys (47\%), the second one being the chemical industry (41\%). Beginning from 2018 the production of metallurgical grade silicon has become unprofitable in many countries, with fabs closing and production figures decreasing. There is a trend for PS production recovery in the nearest 4-5 years though. According to current predictions the PS production growth is expected to accelerate in 2022 and thereafter due to a recovery of base consumption and the rising raw material demand in the semiconductor industry. Over the last decade the demand for metallurgical grade silicon has been supported by the development of solar energy. The electronics and solar energy industries consume $\sim 12-15 \%$ of the world's raw metallurgical grade silicon [2] (Table 1).

\section{Metallurgical grade silicon prices}

The price decline in the 2018-2020 period was caused by the market proficiency as discussed above (Fig. 1). Beginning from 2020 the demand has grown and hence the prices have been up. It was expected that the price growth would be to some extent moderated by the large excess of accumulated production facilities which would not be used for several years. However there was a metallurgical grade silicon price jump in 2021 due to the China production dropdown. In September-October 2021 the prices grew by $300 \%$. The production decline was caused by an energy crisis in China which affected almost half of the Chinese companies. The energy shortage was caused

Table 1. Dynamics and prediction of the world's metallurgical grade silicon production, ths. tpy

\begin{tabular}{|c|c|c|c|c|c|c|c|}
\hline Country / Region & 2018 & 2019 & 2020 & 2021 & 2022 & 2023 & 2024 \\
\hline US & 185.0 & 130.0 & 140.0 & 175.0 & 210.0 & 220.0 & 240.0 \\
\hline Brazil & 218.0 & 202.0 & 198.0 & 220.0 & 235.0 & 245.0 & 250.0 \\
\hline Other American countries & 42.0 & 35.0 & 30.0 & 40.0 & 44.0 & 45.0 & 45.0 \\
\hline EU & 193.4 & 156.3 & 142.0 & 170.0 & 195.0 & 205.0 & 205.0 \\
\hline Other Europe & 225.5 & 231.0 & 251.0 & 258.5 & 281.8 & 320.9 & 336.5 \\
\hline Africa/Middle East & 38.0 & 20.5 & 0.0 & 0.0 & 0.0 & 0.0 & 15.0 \\
\hline Asia and Oceania & 89.8 & 87.0 & 80.5 & 107.5 & 135.0 & 150.0 & 160.0 \\
\hline CIS & 71.8 & 64.1 & 52.0 & 66.0 & 75.0 & 77.5 & 80.0 \\
\hline China & $1,980.0$ & $1,895.0$ & $1,837.5$ & $2,015.0$ & $2,125.0$ & $2,217.5$ & $2,315.0$ \\
\hline Total & $3,043.4$ & $2,820.9$ & $2,731.0$ & $3,052.0$ & $3,300.8$ & $3,480.9$ & $3,646.5$ \\
\hline
\end{tabular}

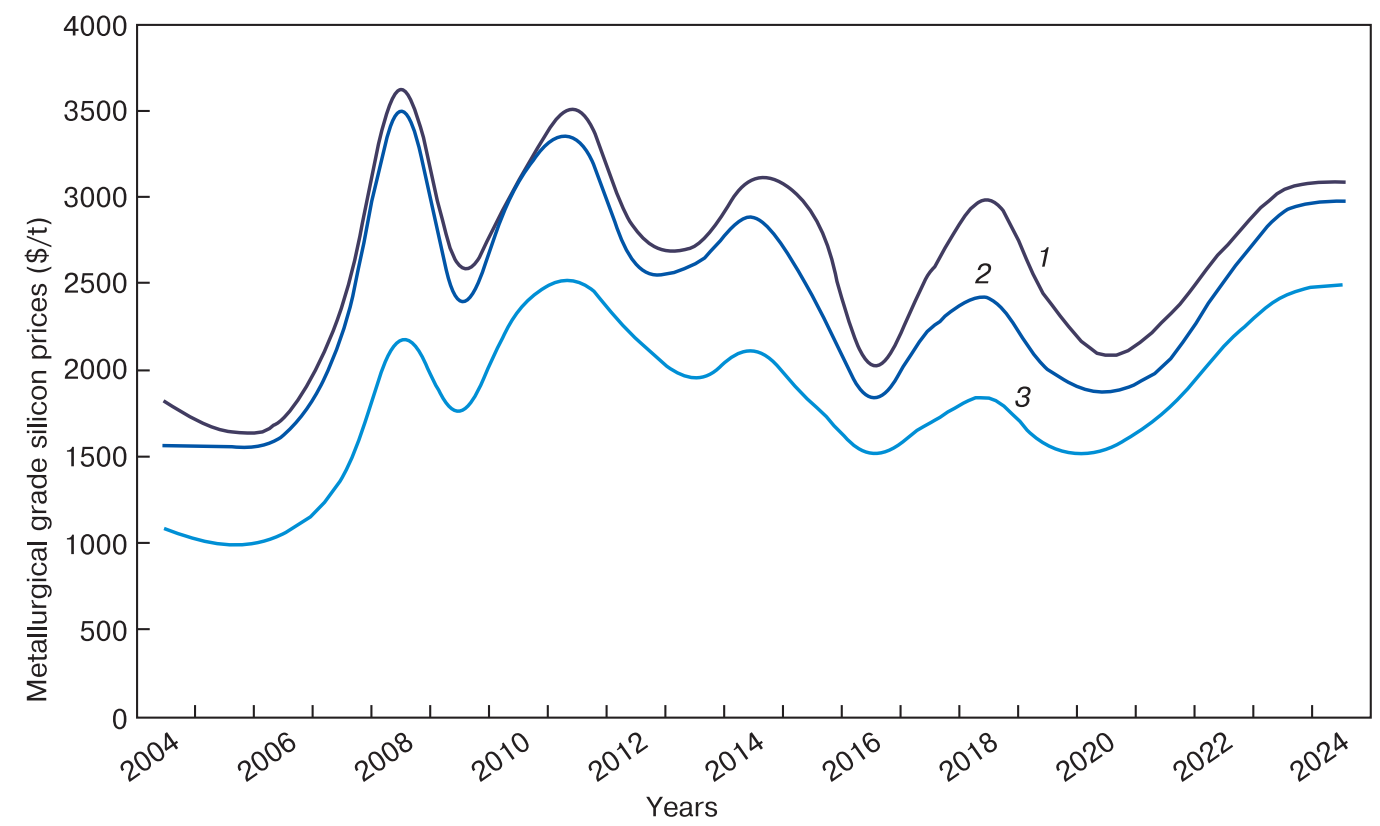

Figure 1. Dynamics and prediction of metallurgical grade silicon prices, \$/t: (1) US, (2) EU and (3) China \& Japan (curves counted top to bottom). 
by China's new atmospheric pollution reduction policy. There is information on the Chinese Government's plans to eliminate carbon footprint by 2060 and their commitment for environmentally safe and low-carbon development. $56 \%$ of China's energy production depends on coal industry, but the Chinese Government has put strict environmental limitations on coal production and implemented top limits of energy consumption for all the Chinese regions. The energy shortage has struck at least $44 \%$ of China's companies, causing operation stoppage at many enterprises including the metallurgical grade silicon ones. The price has also been largely affected by the US sanction policy since a big share of Chinese metallurgical grade silicon production premises are located in the
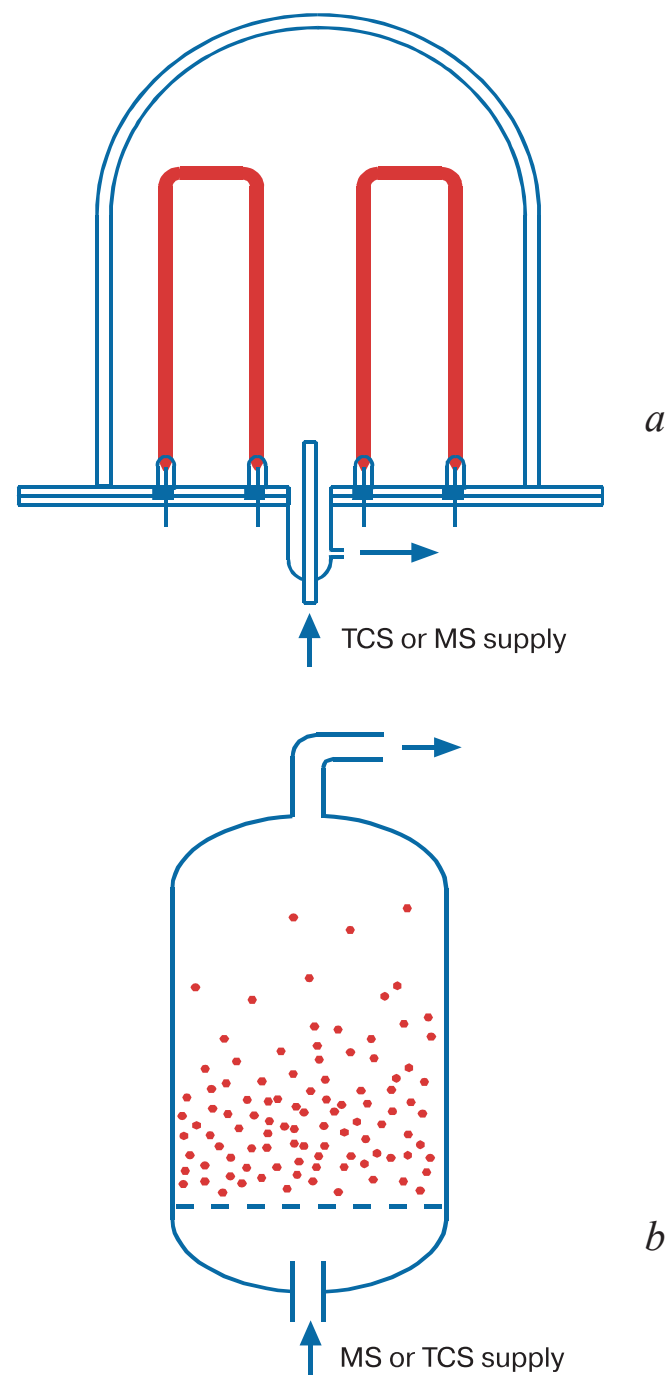

Figure 2. Industrial polysilicon reactor types: (a) Siemens $\mathrm{SiHCl}_{3}$ (TCS) hydrogen reduction or $\mathrm{SiH}_{4}$ (MS) pyrolysis reactor. Hereinafter denoted as Siemens TCS or Siemens MS, respectively. Polysilicon is deposited on seed rods: (a) $\mathrm{SiHCl}_{3}+\mathrm{H}_{2} \rightarrow \mathrm{Si}+3 \mathrm{HCll} ;(b) \mathrm{SiH}_{4} \rightarrow \mathrm{Si}+\mathrm{H}_{2}$; (b) MS decomposition or TCS hydrogen reduction fluidized bed reactor. Hereinafter denoted as FBR-MS or FBR-TCS, respectively. Polysilicon is produced in a granulated form: (a) $\mathrm{SiH}_{4} \rightarrow \mathrm{Si}+\mathrm{H}_{2}$; (b) $\mathrm{SiHCl}_{3}+\mathrm{H}_{2} \rightarrow \mathrm{Si}+3 \mathrm{HCl}$.
Xinjiang Uygur Autonomous Region the Chinese Government's policy toward which is under severe criticism. The Norwegian company Elkem ASA that produces silicones, silicon and other silicon-containing materials has also stopped production. As a result the price of metallurgical grade silicon has soared from $1.2-2.6 \$ / \mathrm{t}$ to $10.4 \$ / \mathrm{t}$ at peak and is currently at 3-4 \$/t.

\section{Industrial polysilicon processes}

Metallurgical grade silicon contains a large number of impurities. Poly-Si production preferably requires purer metallurgical grade silicon (Table 2).

Table 2. Notation and guaranteed parameters of metallurgical grade silicon for solar and electronic grade poly-Si

\begin{tabular}{cccccc}
\hline Grade & $\begin{array}{c}\text { Si } \\
(\mathbf{m i n} \%)\end{array}$ & $\begin{array}{c}\text { Fe } \\
(\mathbf{m a x} \%)\end{array}$ & $\begin{array}{c}\text { Al } \\
(\mathbf{m a x} \%)\end{array}$ & $\begin{array}{c}\text { Ca } \\
(\mathbf{m a x} \%)\end{array}$ & $\begin{array}{c}\mathbf{P} \\
(\mathbf{m a x} \mathbf{~ p p m})\end{array}$ \\
\hline 1101 & 99.79 & 0.1 & 0.1 & 0.01 & 30 \\
1501 & 99.69 & 0.15 & 0.15 & 0.01 & 30 \\
1503 & 99.67 & 0.15 & 0.15 & 0.03 & 30 \\
2202 & 99.58 & 0.2 & 0.2 & 0.02 & 30 \\
2502 & 99.48 & 0.25 & 0.25 & 0.02 & 30 \\
\hline
\end{tabular}

The production of solar and electronic grade polysilicon requires deep purification of metallurgical grade silicon. Industrial processes are illustrated in Fig. 2.

The Siemens TCS process is currently absolutely dominating in the industry. However the gas/vapor mixture output from the reactor contains a large quantity of unreacted $\mathrm{H}_{2}$, TCS, silicon tetrachloride $\left(\mathrm{SiCl}_{4}\right.$ or STC) and polysilanchlorides because only $20-25 \%$ of silicon derived from TCS is deposited onto the seed rods within one cycle, with only about $10 \%$ of $\mathrm{H}_{2}$ supplied to the reactor being involved in the reaction. About $12.5 \mathrm{~kg}$ of $\mathrm{SiCl}_{4}$ forms per $1 \mathrm{~kg}$ of polysilicon.

Historically the first classic approach to this problem was the use of surplus STC for the production of other materials, i.e., pyrogenic $\mathrm{SiO}_{2}$ (aerosil), organic silicon compounds etc. $[1,3,4]$.

Aerosil is often produced by high-temperature silicon tetrachloride hydrolysis. Some poly-Si producers (e.g. Wacker Chemie GmbH, Tokuyama Soda etc.) use by-product tetrachloride for aerosil production. The high-temperature gas phase $\mathrm{SiCl}_{4}$ hydrolysis process is based on the reactions occurring in the hydrogen-oxygen torch upon silicon tetrachloride supply:

$$
\mathrm{SiCl}_{4}+2 \mathrm{H}_{2}+\mathrm{O}_{2}=\mathrm{SiO}_{2}+4 \mathrm{HCl} \text {. }
$$

After aerosil separation from the dust and gas mixture by conventional dry dust removal techniques the effluent gases are exposed to water absorption treatment to produce hydrochloric acid. The whole process can be arranged in a manner so both final products (aerosil and hydrochloric acid) have a high purity. Chlorosilanes are 


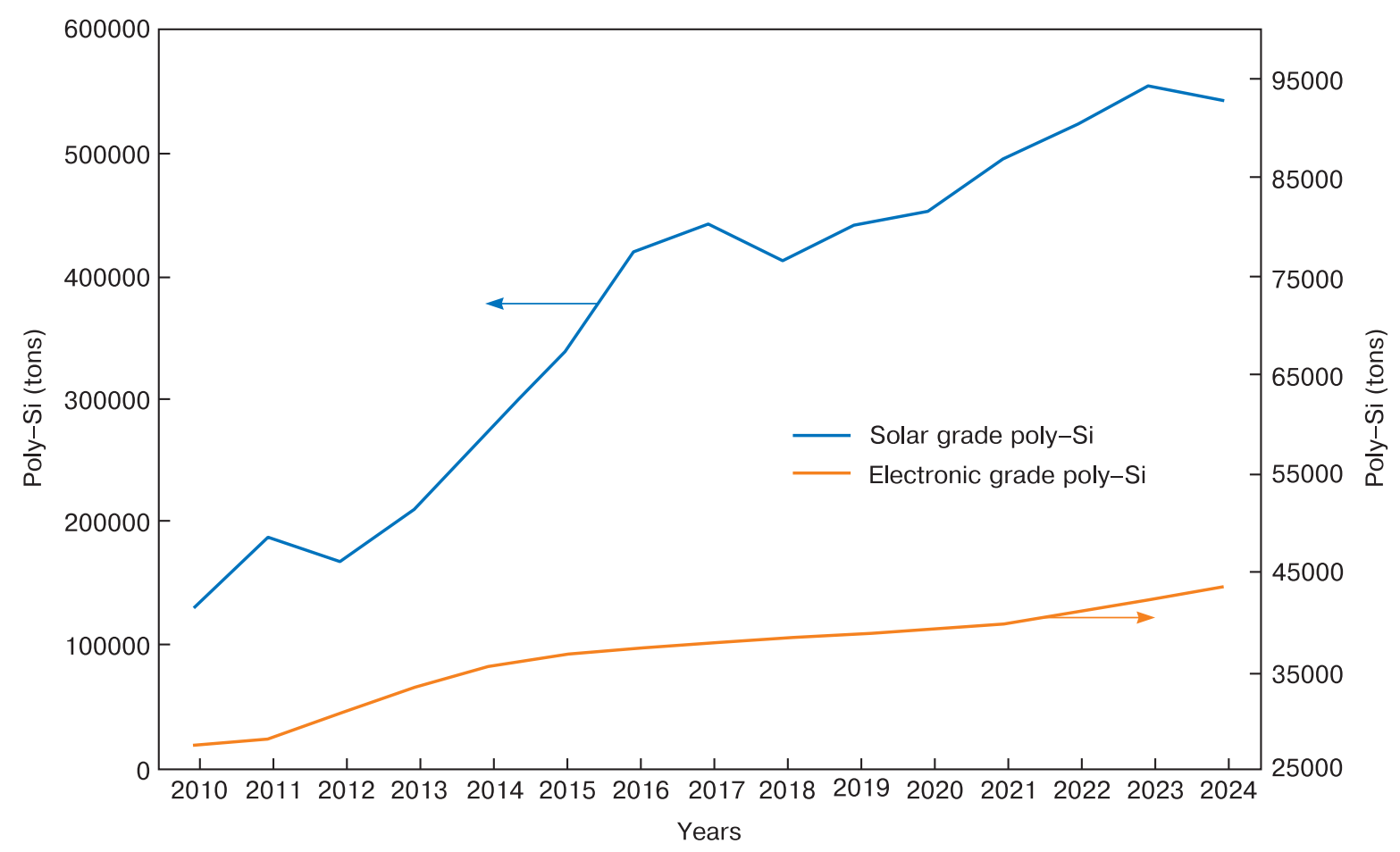

Figure 3. Solar and electronic grade poly-Si consumption: history and prediction. Source: Bloomberg

separated at the first condensate reprocessing stage from the used steam and gas mixture output from the hydrogen reduction plant. After chlorosilane condensate separation, one of the chlorosilane mixture components, i.e., trichlorosilane, is recycled to the silicon production stage and tetrachlorosilane is supplied for aerosil production. For this purpose the silicon tetrachloride vapor is mixed with air and non-condensing gases output from the chlorosilane condensation system. These gases contain hydrogen (about 90 vol.\%) and hydrogen chloride. The torch provides for high-temperature silicon tetrachloride hydrolysis. The effluent gases from the thermal hydrolysis chamber are cleaned with hydrochloric acid solutions and water. The output hydrochloric acid is either exported as a final product or processed to dehydrated hydrogen chloride. This method provides for the simultaneous disposal of hydrogen-containing gas, silicon tetrachloride and hydrogen chloride. These products can be separated as pure substances. The above described technology allows producing high-purity silicon dioxide with a controlled grain size (1-20 $\mu \mathrm{m}$ for fiber optics applications and 1-100 $\mu \mathrm{m}$ for semiconductor electronics). Grain size control is achieved by inert-gas dilution of silicon tetrachloride vapors contacting with the water-containing absorbent.

However since the early 2000s the Siemens-TCS poly-Si amounts of each specific producers have grown to such a high level that the disposal of excess STC has become technically and economically unviable.

The task has therefore arisen to use excess STC for poly-Si production. Then the Siemens-TCS process was split in two modifications: Siemens DC and Siemens HC. The hydrogen reduction products output from the reactor

Table 3. Solar and electronic grade poly-Si parameters

\begin{tabular}{|c|c|c|}
\hline Parameters & Electronic grade & Solar grade (mono-grade) \\
\hline Main substance fraction & $>99.999999999(>11 \mathrm{~N})$ & 99.999999-99.999 $999999(8-11 N)$ \\
\hline Use & $\begin{array}{l}\text { Microelectronic and high-power Si single } \\
\text { crystal devices }\end{array}$ & Si single crystal photoelectric converters \\
\hline Donors & $\begin{array}{c}(\mathrm{P}, \mathrm{As}, \mathrm{Sb})(n \text {-type, } \rho \geq 1000 \mathrm{Ohm} \cdot \mathrm{cm}) \\
\leq 0,05 \mathrm{ppba}\end{array}$ & $\begin{array}{c}(\mathrm{P}, \mathrm{As}, \mathrm{Sb})(n \text {-type, } \rho \geq 500 \mathrm{Ohm} \cdot \mathrm{cm}) \\
\leq 0,1 \mathrm{ppba}\end{array}$ \\
\hline Acceptors & $\begin{array}{c}(\mathrm{B}, \mathrm{Al})(p \text {-type, } \rho \geq 9000 \mathrm{Ohm} \cdot \mathrm{cm}) \\
\leq 0,03 \mathrm{ppba}\end{array}$ & $\begin{array}{c}(\mathrm{B}, \mathrm{Al})(p \text {-type, } \rho \geq 5000 \mathrm{Ohm} \cdot \mathrm{cm}) \\
\leq 0,05 \mathrm{ppba}\end{array}$ \\
\hline Carbon $(\mathrm{C})$ & $\leq 0,1 \mathrm{ppma}$ & $\leq 0,2$ ppma \\
\hline $\begin{array}{l}\text { Metals: } \\
\quad \text { - in the bulk (Fe, } \mathrm{Cu}, \mathrm{Ni}, \mathrm{Cr}, \mathrm{Zn}, \mathrm{Na}) \\
\text { - on the surface }(\mathrm{Fe}, \mathrm{Cu}, \mathrm{Ni}, \mathrm{Cr}, \mathrm{Zn}, \mathrm{Na})\end{array}$ & $\begin{array}{l}\leq 0.5 \text { ppbw } \\
\leq 1 \mathrm{ppbw}\end{array}$ & $\begin{array}{l}\leq 0.5 \text { ppbw } \\
\leq 1 \mathrm{ppbw}\end{array}$ \\
\hline Minority carier lifetime (more than) & $400 \mathrm{mks}$ & $250 \mathrm{mks}$ \\
\hline
\end{tabular}


had to be completely regenerated by condensation and $\left(\mathrm{SiHCl}_{3}+\mathrm{SiCl}_{4}\right)$ mixture separation. Therefore there are two approaches to handling large $\mathrm{SiCl}_{4}$ amounts forming as by-products during TCS hydrogen reduction:

- excess $\mathrm{SiCl}_{4}$ conversion to TCS in special converting reactors (the so-called Siemens-DC method, sometimes referred to as clean recycling):

$$
\mathrm{SiCl}_{4}+\mathrm{H}_{2} \rightarrow \mathrm{SiHCl}_{3}
$$

- recycled $\mathrm{SiCl}_{4}$ supply to the initial TCS synthesis reactor (the so-called Siemens-HC method or dirty recycling):

$$
\mathrm{Si}_{\mathrm{MG}}+2 \mathrm{H}_{2}+\mathrm{SiCl}_{4} \rightarrow 4 \mathrm{SiHCl}_{3} \text {. }
$$

Both these approaches are currently equally used by leading companies. The economic parameters of these processes seem to be close. The Siemens-HC process is believed to be more capital-consuming $[1,5]$.

\section{Current poly-Si market condition}

Aimed at optimizing their production costs the poly-Si producers have clearly delimited the quality of their product material for various purposes. As a result the following terms have emerged:

- poly-Si for multi-silicon production by casting or solar grade poly-Si for multicrystalline cells (multi grade) with a purity of $99.99999 \%(7 \mathrm{~N})-99.999999 \%(8 \mathrm{~N})$;
- poly-Si for solar grade single crystal silicon production by the Czochralski method or solar grade poly-Si for monocrystalline cells (mono grade) with a purity of $9 \mathrm{~N}$ to $11 \mathrm{~N}$;

- electronic grade poly-Si for semiconductors with a purity of $11 \mathrm{~N}$ or higher.

Electronic grade poly-Si is produced and consumed in an amount of about 35-40 ths. tpy. The solar grade poly-Si production has exceeded 500 ths. tpy (Fig. 3).

However the quality of electronic grade PS and purest solar grade poly-Si which is also intended for $\mathrm{Cz}$ single crystal growth differs considerably (Table 3).

The number of poly-Si production facilities has grown multiply over the two last decades. Intense growth periods have often caused significant facility excess in turn leading to price drop (Fig. 4).

The poly-Si market currently sees a slight reduction of excess facilities and a price growth after a long price decline period (7-8 $\$ / \mathrm{kg}$ ), see Fig. $5 a$ and $b$. It is however anticipated that the offer will be still above the demand for several years ahead $[5,6]$.

\section{Main poly-Si producers}

Over the recent 3-4 years the world's distribution of poly-Si producing companies has changed dramatically. The traditional PS production leaders such as Wacker (Germany), Hemlock (US), REC (Norway-US), Tokuyama (Japan), SunEdison (former MEMC Electronic Materials, US) have lost the top positions both in product output and in production efficiency. The multi-year efficiency leaders Wacker and Hemlock lost their top positions

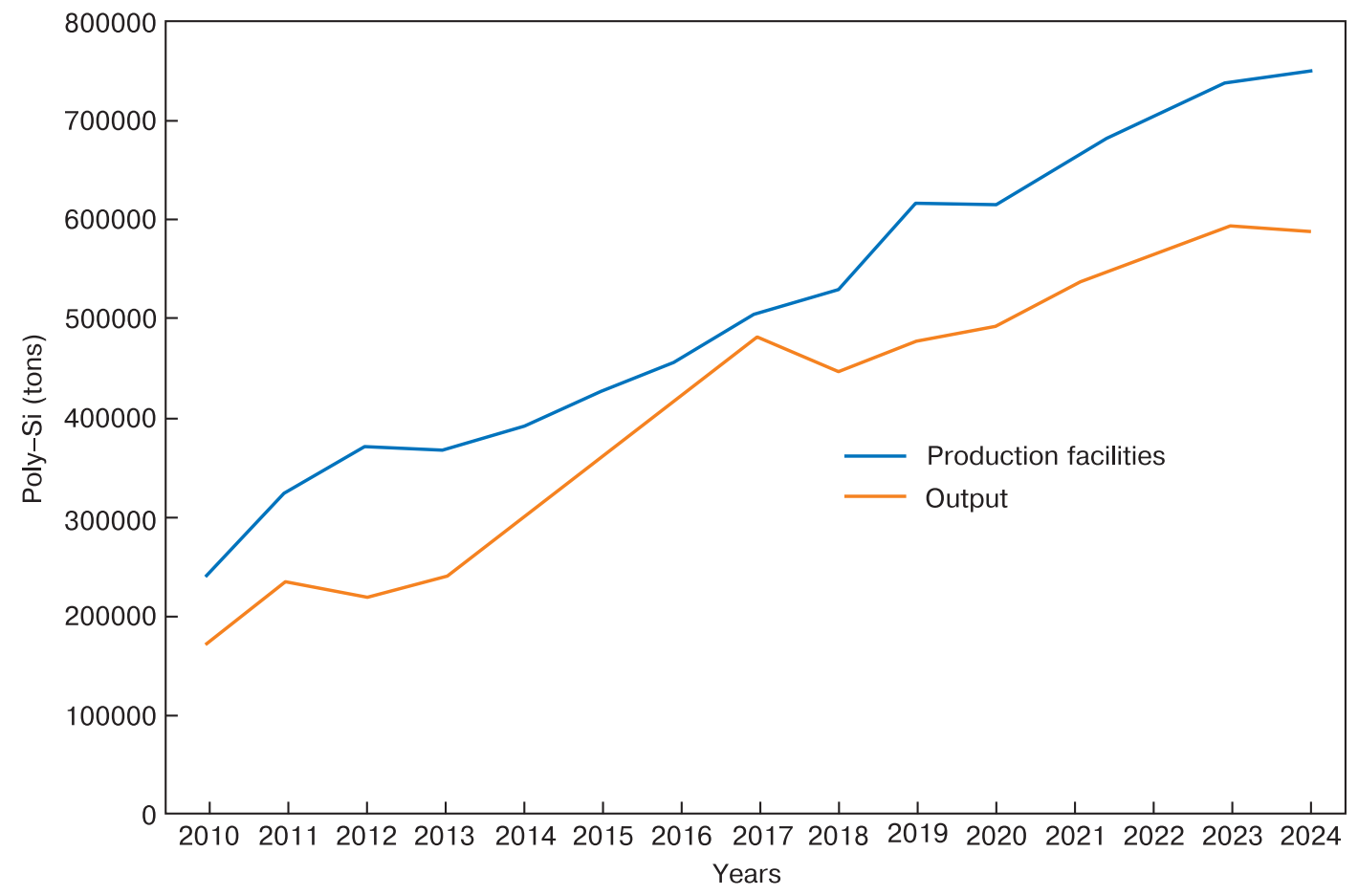

Figure 4. Growth of the number of poly-Si production facilities and actual output (solar + electronic grade) in $2004-2024$. Source: Bloomberg. 
back in 2018 (Hemlock has furthermore fallen a prey of Chinese counter-sanctions and had to greatly reduce its product output). One should however take into account that these companies as well as the Japanese Tokuyama and Mitsubishi ones are the main producers of the more resource-consuming and costly electronic grade poly-Si (Fig. 6).

In 2019-2021 the situation changed even greater. According to different estimates, the world's total polysilicon production reached $521-545$ ths. $t$ in 2020 with about 440 ths. $t$ being produced in China. Preliminary

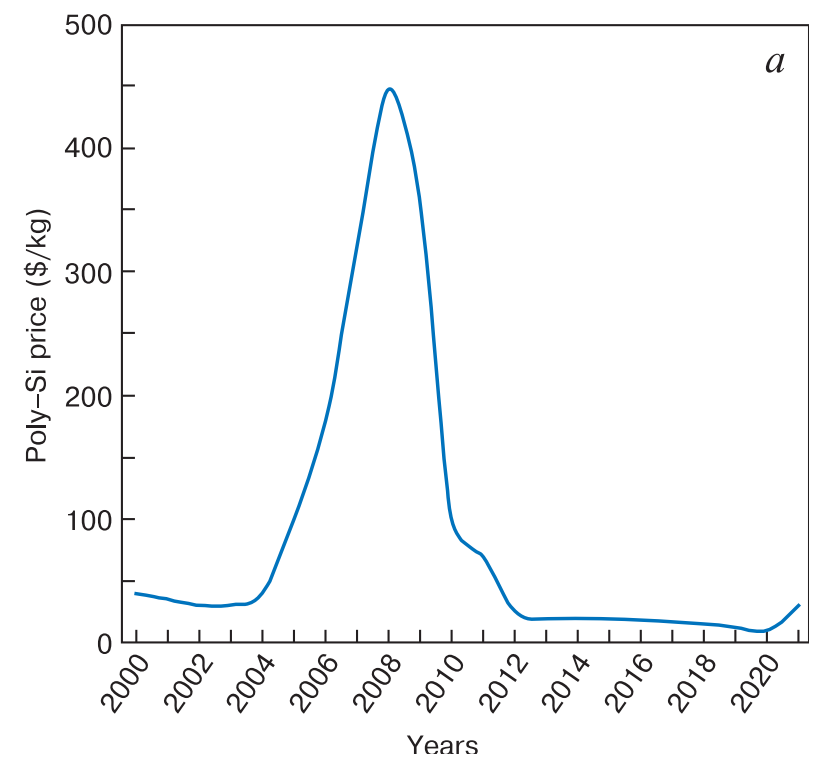

estimates suggest that the world's total PS production was 546-575 ths. $t$ in 2021 of which China produced 470 ths. $\mathrm{t}$ (more than $80 \%$ ), see Fig. 7.

It should be expected that after 2021 the worldwide domination of the Chinese solar grade poly-Si producers will further strengthen.

Along with a $71 \%$ solar cell offer share in the world's market in 2019 China also had a $97 \%$ share of the world's semiconductor wafer production, a $79 \%$ share of solar cell production and a $79 \%$ share of polysilicon production. In 2020 China already gained a $80 \%$ share of poly-Si

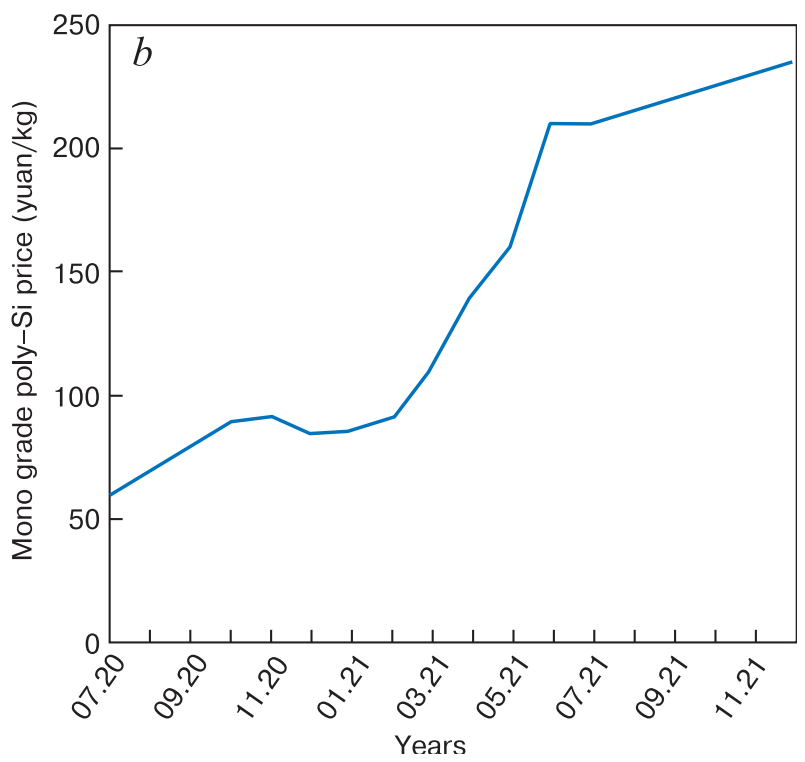

Figure 5. Solar grade silicon price dynamics: (a) 2002-2021 (\$/kg), (b) July 2020 - December 2021 (¥/kg). Source: Bernreuter Research.

Table 4. Production build-up plans of some poly-Si producers

\begin{tabular}{|c|c|c|c|c|}
\hline Company & Location & Planned output (ths. t) & Terms & Comments \\
\hline \multirow{4}{*}{ GCL-Poly } & Xinjiang & 20,000 & Start in 2021 & \multirow[t]{2}{*}{ Conventional Siemens process } \\
\hline & Leshan & 100,000 & Start in 2022 & \\
\hline & Xuzhou & 100,000 & $1^{\text {st }}$ stage in 2021 & Granulated silicon \\
\hline & Baotou & 300,000 & $1^{\text {st }}$ stage of 60,000 tons planned & \\
\hline \multirow[t]{2}{*}{ Xinte } & Baotou & 200,000 & $1^{\text {st }}$ stage of 100,000 tons planned & \multirow[t]{2}{*}{ Conventional Siemens process } \\
\hline & Leshan & 35,000 & Start in $2021 \mathrm{Q} 3$ & \\
\hline \multirow[t]{2}{*}{ Tongwei } & Baotou & 45,000 & Start in 2022 & \multirow[t]{2}{*}{ Conventional Siemens process } \\
\hline & Baoshan & 40,000 & Start in $2021 \mathrm{Q} 4$ & \\
\hline Tongwei TRW & Baotou & 40,000 & Start in 2022 & Conventional Siemens process \\
\hline Tongwei Jinko & Leshan & 45,000 & Start in 2022 & Conventional Siemens process \\
\hline Dazhi New Energy & Xinjiang & 35,000 & Start in 2021 & Conventional Siemens process \\
\hline Asia Silicon Industry & Shinin & 60,000 & 30,000 tons in early 2022 & Conventional Siemens process \\
\hline OCI & Malaysia & 5000 & Start in 2022 & Conventional Siemens process \\
\hline Jiangsu & Shimin Shan & 100,000 & N/A & Conventional Siemens process \\
\hline $\begin{array}{l}\text { TBEA; JinkoSolar; } \\
\text { JA Technology }\end{array}$ & Baotou & 100,000 & June 2023 at latest & Conventional Siemens process \\
\hline Tongwei shares & Leshan & 200,000 & Start in December 2022 & Conventional Siemens process \\
\hline Xinjiang Jingnuo & Hug & 100,000 & N/A & Conventional Siemens process \\
\hline
\end{tabular}




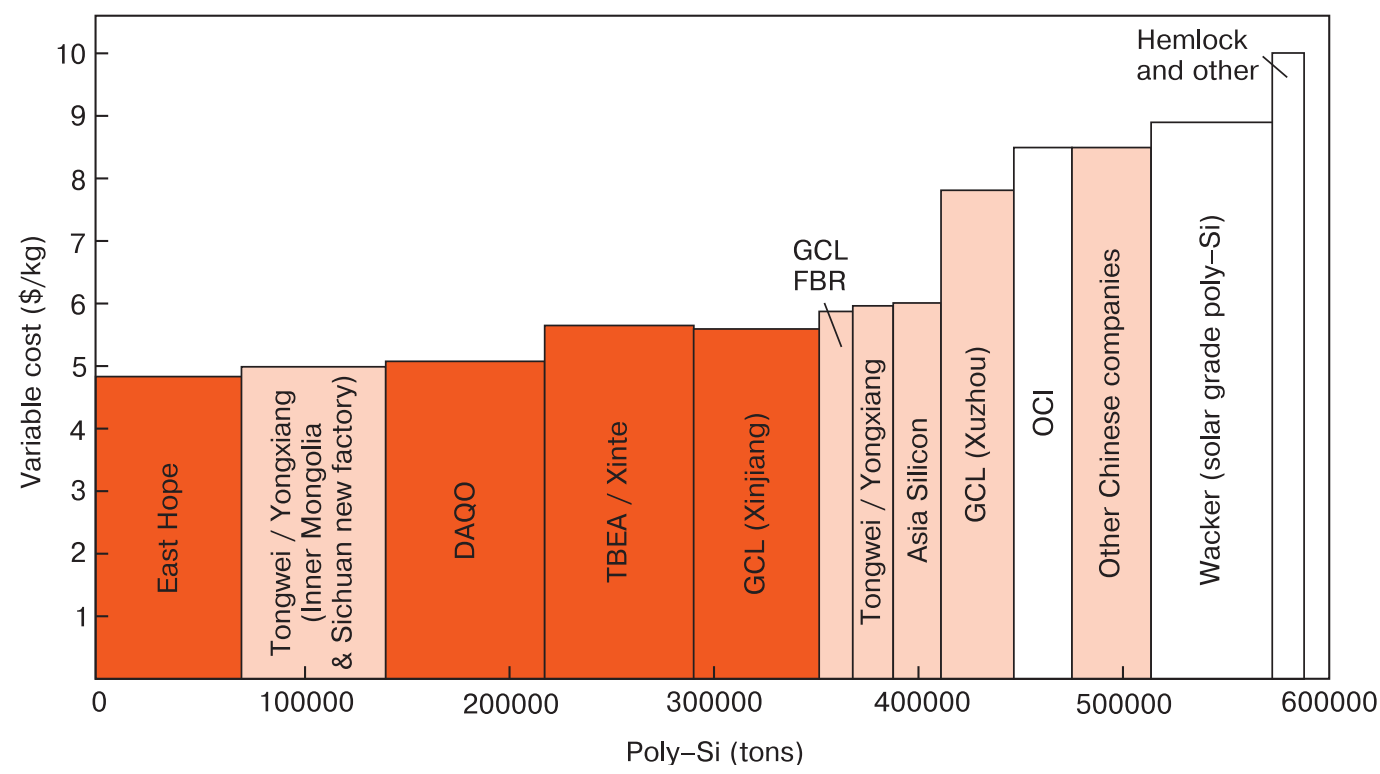

Figure 6. Efficiency and product output of major poly-Si producers in 2021. Source: Bloomberg

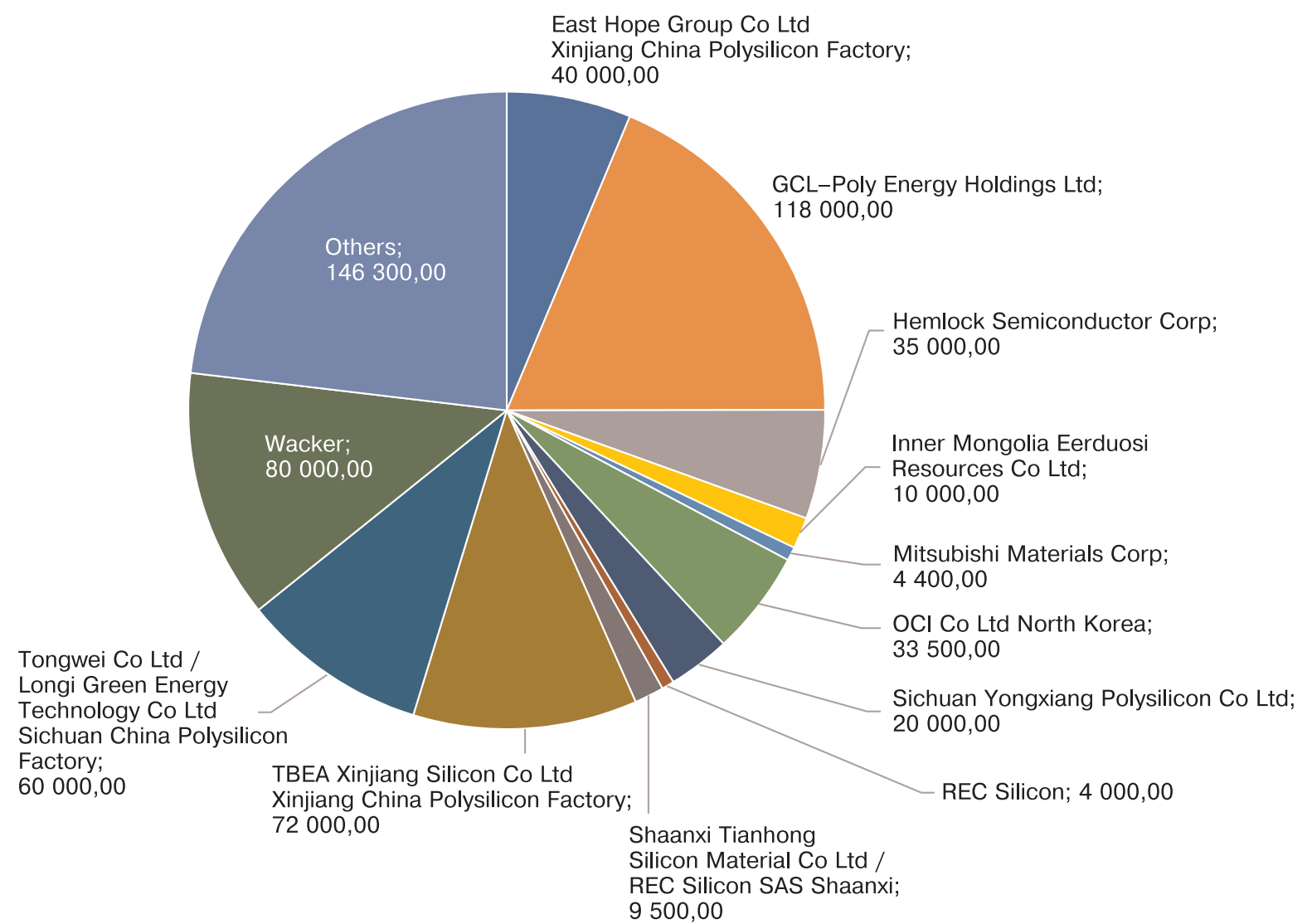

Figure 7. Poly-Si production in 2021. Source: Bloomberg.

production facilities worldwide. All the Chinese poly-Si producers have plans to build up their production facilities (Table 4).

Back in 2012-2013 many Chinese poly-Si producers reduced their outputs, stopped production or went bankrupt due to the then persisting production efficiency lag of some Chinese poly-Si facilities in comparison with the process efficiency of conventional US, German etc. producers. That lag has significantly reduced in recent years thanks to the development of reactor effluent gas recycling technologies and the construction of low energy consuming premises in China. For example, Daqo New Energy Corp. was back in 2017 among the first ones to announce poly-Si cash cost cutdown to $8.95 \$ / \mathrm{kg}$. 
Daqo New Energy Corp. will invest in the construction of four more facilities in 2022. The Company plans a $¥ 33.3$ bn ( $\$ 5.2$ bn) investment into its projects. More than $70 \%$ of that investment will be allocated for the start of two premises in Baotou (Inner Mongolia Autonomous Region). One of these premises will produce 200,000 tpy poly-Si and the other, 21,000 tpy. The construction of these two premises will start in 2022 Q1, and their first stages are to be finished by 2023 Q2. The other portion of the investment ( $¥ 8$ bn or $\$ 1.4$ bn) will be spent for the other two projects in Baotou. Those facilities will have a design output of 300,000 tpy poly-Si and 200,000 tpy organic silicon compounds [7-9].

Some analysts expect the poly-Si market proficiency to remain after 2024. Most Chinese producers build new facilities though. This seems to be caused by the announced "green turn" world over and the continuing separation of international markets into politico-economic blocks in which each market participant aims at own development. Furthermore China invests much in green technologies and the development of environment friendly power production, and therefore its internal markets become the main development driver for Chinese companies.

Of the three formerly existing US poly-Si producers (Hemlock Semiconductor Group, SunEdison (MEMC Electronics) and Renewable Energy Corp.) only Hemlock is still in the market. The Company's overall solar grade poly-Si output is 18 ths. tpy. Hemlock is the only electronic grade poly-Si producer that uses the Siemens-MS process for the zone-melt production of high-ohmic single crystal silicon for high-power electronics.

Wacker Chemie, Germany, has built up its output to 84 ths. tpy.

Of the Korean poly-Si companies only OCI (former DC Chemical) with a 27 ths. tpy output has remained operating.

Polysilicon was produced by four Japanese companies Tokuyama, Mitsubishi, OSAKA Titanium Technologies and M. SETEK. M. SETEK only produced solar grade poly-Si, with all its premises being localized in China.

Only Mitsubishi remains now out of the Japanese silicon producers. We have no data on the current status of the other three Japanese companies. One can assume that only the electronic grade PS producers have survived [10-12].

It should be noted that since recently there has been a vertical integration trend among the Chinese companies running a high risk of problems with poly-Si purchases at acceptable prices: most of China's new premises are designed solely for in-house supply purposes.

\section{Notes about the fluidized bed reactor process}

The use of the monosilane technology (Fig. $2 b$ ) has a number of theoretical advantages [3, 13]:
- $\mathrm{SiH}_{4}$ decomposition occurs at a relatively low temperature and with lower energy consumption;

- the reaction products contain corrosive chemicals (hydrogen chloride, chlorosilanes etc.) that reduce the purity of the product poly-Si;

- $\mathrm{SiH}_{4}$ cleaning from most impurities is more efficient due to the differences between the properties of $\mathrm{SiH}_{4}$ and other compounds.

Therefore the monosilane technology was for that time supported by many researchers. The currently most widely used $\mathrm{SiH}_{4}$ technology is a Union Carbide developed process starting with $\mathrm{Si}$ hydrochlorination: $\mathrm{Si}+3 \mathrm{SiCl}_{4}+$ $2 \mathrm{H}_{2} \rightarrow \mathrm{SiHCl}_{3}$ followed by disproportioning $4 \mathrm{SiHCl}_{3} \rightarrow$ $3 \mathrm{SiCl}_{4}+\mathrm{SiH}_{4}$ and finally $\mathrm{SiH}_{4}$ purification and supply to the reactor for pyrolysis and poly-Si production: $\mathrm{SiH}_{4} \rightarrow \mathrm{Si}+2 \mathrm{H}_{2}$.

However the progress in the Siemens-TCS process was so swift that it could replace all the other polysilicon technologies: they simply had no time to evolve from the prototyping to industrial stage in the course of process development. The only exclusion is the FB-MS or FBR process whose developers claimed to achieve a polysilicon cash cost of below $10 \$ / \mathrm{kg}$. The first large FBR polysilicon premise was built by Ethyl Corporation in the 1980s, and MEMC Electronic Materials (nowadays SunEdison) resumed that project in the 1990s.

As the interest to this technology grew, Wacker Chemie set up a small FBR-TCS facility in 1993 and REC started a big FBR-MS project in 1995. In 2010 SunEdison and Samsung signed a memo for the construction of a 10 ths. tpy facility in Texas. In 2012 GCL-Poly, China, announced a start-up of pure monosilane facility being the first step toward the construction of an FBR-MS polysilicon plant. In 2016 GCL-Poly bought the FBR-MS assets and technology from SunEdison thus reserving for itself sufficient time and making investment into the promotion of this polysilicon technology. In 2021 GCL-Poly announced a significant breakthrough in the development of its FBR-MS process. In the same year GCL-Poly built a FBR-MS granulated polysilicon production line with a 10 ths. tpy output and a customer-verified high granulated polysilicon quality. GCL-Poly claimed a significant advance in the key quality parameters.

Until recently the polysilicon grains growing at reactor walls have had high metallic impurity content. Finally, the FBR process produces a lots of silicon dust which cannot be used for the intended purpose.

In 2021 GCL-Poly claimed all its FBR-MS processes to deliver the same product quality as the Siemens TCS process. The company has run long-term R\&D including the improvement of reactor inner wall lining and currently maintains low production costs while improving product quality. For example it has tangibly reduced the quantity of contaminants. At the current process development stage the overall metallic impurity content in GCL-Poly's poly-Si is near 10 ppbw, the carbon content is below 0.4 ppma and the hydrogen content is below 20 ppma. 
The hydrogen expense at the output of GCL-Poly's 10,000 tpy line is almost $30 \%$ lower than that for another 6000 tpy line built by GCL-Poly earlier. Furthermore the fine-grained powder content was reduced to $0.1 \%$. As for the output, GCL-Poly claims its FBR-MS process has reached a $99 \%$ yield for total granulated polysilicon and $90 \%$ specifically for granulated polysilicon that can be used for single crystal Si growth.

As compared with the Siemens process the FBR-MS one delivers lower power consumption. However until recently this advantage had been offset by a high fraction of ultrafine silicon powder in the final product. FBR-MS polysilicon grains produced by GCL-Poly have a spherical shape and a diameter of about $2 \mu \mathrm{m}$. These grain parameters not only comply with the specifications for single crystal Si growth charge but also are compatible with automated crucible charging systems (due to charge loading and transportation simplicity). Furthermore the line on the basis of this technology has only required a $¥ 700$ mln investment, its power consumption being within $20 \mathrm{kWh} / \mathrm{kg}$. GCL-Poly claims that by and large its granulated polysilicon produced by this process is suitable as charge for mono-Si production. In 2020 GCL-Poly's granulated silicon demo project was officially started in Xuzhou and became another step toward industrial scale granulated silicon production. Currently GCL-Poly has granulated silicon premises in Xuzhou and according to preliminary data it had produced about 30,000 tons of polysilicon by late 2021 . The Company plans expanding its premises to satisfy the growing demand and it will produce 100,000 tpy of granulated silicon since early 2022 in Leshan. It has furthermore signed a memo for the production of 300,000 tpy of granulated silicon for R\&D at Shangshu Machine Control. The first stage of the premises having a design output of 60,000 tpy is planned for starting in Baotou, see Table 4 [14].

GCL-Poly's large investment in granulated silicon production suggests the high promise of this market.
Granulated silicon has the advantage of low power consumption combined with uninterrupted production process. It also compensates the weak points of the Siemens TCS process. Large-scale production and use of granulated silicon will complement the Siemens TCS process by providing a good additional material for polysilicon crucible charging along with Siemens-TCS polysilicon due to better crucible filling. Also noteworthy, FBR-produced grains are the perfect material for the implementation of uninterrupted additional loading $\mathrm{Cz}$ single crystal growth. According to some estimates the SiemensTCS PS production reached 511.1 ths. t, i.e., $98.1 \%$, in 2020. 9.9 ths. $t$ was produced using the FBR-MS process which is $1.9 \%$. Preliminary estimates show that the Siemens-TCS poly-Si production was 535 ths. $t$ in 2021, the FBR-MS figure being 11 ths. $\mathrm{t}$ [15-18].

\section{By-product output}

As noted above, of extreme importance for the Siemens-TCS process is the choice of the disposal or use variants for excess silicon tetrachloride. It is safe to say that the solution of this task will determine the success of new projects [3].

The main application domains of silicon tetrachloride and its derivatives are summarized in Table 5.

\section{Metallurgical grade silicon production in Russia and the CIS}

It can be seen from Table 6 that the development of Russian poly-Si production requires primarily the solution of the stable raw material supply problem.

However the main problem was that until 2021 the development of poly-Si production in Russia faced a low

Table 5. Main application domains of silicon tetrachloride and its derivatives [4]

\begin{tabular}{|c|c|}
\hline Material & Application domain \\
\hline Silicon Tetrachloride & $\begin{array}{l}\text { Silicon epitaxy, semiconductor silicon, solar grade silicon, fiber-optic light guides, silica gel, organic chlorosila- } \\
\text { nes, organic silicon polymers, hydrosilisic acid, steel silicification }\end{array}$ \\
\hline Ethyl silicate & $\begin{array}{l}\text { Precision casting molds, corrosion resistant coatings, thermostable paints, solar cell array materials, lubricant } \\
\text { silicones, special purpose transformer oils, high-temperature heat exchange liquids, diffusion pump oils, modified } \\
\text { resins, thermostable glues, silicon oxide films for semiconductor surface masking, plastics, polymers }\end{array}$ \\
\hline $\begin{array}{l}\text { Aerosol silicon dioxide } \\
\text { (aerosil) }\end{array}$ & $\begin{array}{l}\text { Resin and glue fillers, aerosols, cosmetics, medicines, lubricants, polishing materials, chemicals, quartz, thixotrop- } \\
\text { ic thickeners in paints and varnishes, plastic and rubber fillers }\end{array}$ \\
\hline Quartz including high-purity & $\begin{array}{l}\text { Crucibles, growth boats and other containers for the synthesis, processing and storage of high-purity materials, lab } \\
\text { equipment and containers, pipes, pipe fittings, devices, illuminators, sight glasses, optical devices, light engineer- } \\
\text { ing items, optics }\end{array}$ \\
\hline Silicon nitride & $\begin{array}{l}\text { High-temperature units and parts, jet propulsion engine nozzles, lining and other missile parts, melting crystal- } \\
\text { lization and diffusion containers for high-purity material processes, thermocouple sheaths, neutron sink prime } \\
\text { (hafnium) }\end{array}$ \\
\hline Silicon carbide & Protective coatings (e.g. hafnium coatings in epitaxial plants) electronics \\
\hline Tetraoxysilane & glass, aerosil, quartz, silicon dioxide insulating layers for semiconductor devices, silicon polymers \\
\hline
\end{tabular}


Table 6. CIS total premises as by 2021 [2]

\begin{tabular}{ccccc}
\hline Country & Plant & Year started & Output (ths. tpy) & Comments \\
\hline Ukraine & ZalK, Silicon shop & 1938 & 25 & Demolished \\
Russia & UAZ, Silicon shop & 1942 & 26 & Stopped in 2019 \\
Russia & IrkAZ, Silicon shop, since 1988 & 1981 & 34 & $2^{\text {nd }}$ stage stopper in 2020, 4 ovens of \\
& Kremnii Rusal CJSC & & 40 & Changed to FeSi produceion since \\
Russia & BrAZ, Silicon shop & 1987 & 2000 \\
Kazakhstan & Tau Ken Temir JSC & 2009 & 24 & Stopped in 2019 \\
\hline
\end{tabular}

domestic demand (700-800 tpy) and low world market prices which hindered the establishment of exportation-oriented premises. We however see that the overall situation has finally started to change, though slowly:

- Russian authorities have decided to further develop solar energy industry and build a $1 \mathrm{GW}$ solar cell fab in the Kaliningrad Region (EnCOR). This fab will consume large quantities of silicon wafers that can hardly be provided under third-party contracts with foreign suppliers, and it should also be borne in mind that high-quality $n$-conductivity type wafers are required. Furthermore, Solar Systems Co. also has a single crystal silicon plant in Podolsk and claims to have increased its production facilities. Therefore the poly-Si demand for sole single crystal production will be about 7 ths. tpy which is close to the expert-recommended poly-Si production figure of 10 ths. tpy that can maintain a competitive product cost. The poly-Si, single crystal and wafer production facilities should be for the time being localized in Russia.

- implementation of fully domestic microelectronics production cycle is an important strategic task for Russia. The Russian electronics industry development strategy envisions a 2.7 times growth in the share of domestic electronics products in the Russian market by 2030 . There is every evidence that the Russian Government have the firm intention to finally put away the sore problem faced by the microelectronics industry. Analysis of their approaches and comparison with the former policy suggests there is a big chance the problem will be finally solved somehow. If the future poly-Si project includes electronic grade poly-Si production, there will be a State support opportunity along with the purely economic advantage.

- the world's solar grade poly-Si prices have seen a growth since recently. This opens a certain window of opportunity. Taking into account the market volatility and quite probable price drops the future poly-Si production project should be designed so its OPEX be at a level of the current worldwide solar grade poly-Si companies' best price indicators (within $10 \$ / \mathrm{kg}$ ).

- Russia has other electronics and photonics fields which urgently need domestic raw materials sources, i.e., the production of extra high purity quartz and glass. The choice of excess STC disposal and TCS production methods will improve the project economic parameters and solve important related industry tasks. High-temperature silicon tetrachloride hydrolysis is used for the production of high-purity synthetic quartz items, e.g. crucibles, melting boats, pipes and optics [4]. A specific feature of synthetic quartz derived from silicon tetrachloride is an extreme purity. The total of impurities (aluminum, iron, calcium, boron etc.) in highest purity rock crystal is far above that for synthetic quartz.

The USSR-developed synthetic quartz technology (implemented at the Podolsk Chemical and Metallurgical Plant) on the basis of high-temperature hydrolysis of silicon tetrachloride purified to a $1 \cdot 10^{-4}-1 \cdot 10^{-7} \mathrm{wt} . \%$ total impurity content delivers a material with a total impurity content of within $1 \cdot 10^{-4}-1 \cdot 10^{-5}$ by weight. This quartz is by 1-2 orders of magnitude purer than natural one. For the high-temperature hydrolysis method high-purity fine-grained silicon dioxide with a $0.1-100 \mu \mathrm{m}$ particle size forms in the hydrolysis torch by analogy with aerosil production. The dioxide is sputtered onto an inert material shaping mold. The porous workpiece so formed is then compaction-sintered at $1400-1500{ }^{\circ} \mathrm{C}$ with shape correction. Similar processes are used for light-guide fiber drawing workpieces used in fiber optic technologies. Quartz use for fiber optics emphasizes the problem of hydroxyl group contamination that dramatically reduces the light conductivity of quartz fiber. The hydroxyl content in synthetic quartz produced in a hydrogen-containing gas torch (hydrogen, methane etc.) is (1-5) $\cdot 10^{-2} \mathrm{wt} \% \%$ [4] .

This of course does not depreciate the necessity of improving the existing Siemens processes. Some authors believe that now it is the time to correct the overall approach to the advanced Siemens production of technical grade silicon $[2,19-21]$ :

- refusal from the power-consuming technical grade silicon production and trichlorosilane synthesis technologies due to a transition to direct chlorination of specially prepared silica, $\mathrm{SiCl}_{4}$ production and subsequent low-temperature hydration to $\mathrm{SiHCl}_{3}$;

- ruling out environment-polluting polycrystalline rod mechanical crushing and cutting technologies by replacing them for advanced "non-contamination" (electrohydraulic crushing, blistering etc.);

- use of monosilane for Siemens process recycling system replenishment.

\section{Conclusion}

In our opinion the poly-Si market is entering a new development phase. With some market proficiency being re- 
tained on the whole, the "green turn" of the energy industry announced by all the governments, the development of local markets and the price recovery to an investment attractive level have promoted the development of new poly-Si fab projects. However the new projects should comply with the best practices elaborated during the low price period.

The domestic solar energy industry has finally approached the threshold beyond which the entire process chain of photovoltaic products becomes profitable. In turn the large-scale fabrication of photovoltaic cells and arrays will give an impetus to the development of elated industries (production of accessories and consumables, e.g. composite and isostatic graphite items, laminating films, process gases, magnetron targets and many other products). Furthermore there will be economic grounds for the fabrication of related equipment the supplies of which are hindered by COVID epidemic consequences or sanction-related restrictions and concerns. A cornerstone problem will doubtlessly be the development of poly-Si production which stopped after the collapse of the USSR

\section{References}

1. Naumov A.V., Parkhomenko Yu.N. New reality of the polysilicon market. XI Intern. conf. on topical issues of physics, materials science, technology and diagnostics of silicon, nanoscale structures and devices based on it ("Silicon-2018"). Chernogolovka, 2018, p. 11. (In Russ.)

2. Eremin V.P., Eliseev I.A. The state of silicon production in Russia and the world, its refining to high grades and "solar" quality. XIII Intern. conf. on topical issues of physics, materials science, technology and diagnostics of silicon, nanoscale structures and devices based on it ("Silicon-2020"). Yalta, 2020, p. 44. (In Russ.)

3. Falkevich E.S., Pulner E.O., Chervony I.F. Shvartsman L.Ya. Semiconductor silicon technology. Moscow: Metallurgy, 1992, 408 p. (In Russ.)

4. Sivoshinskaya T.I., Grankov I.V., Shabalin Yu.P., Ivanov L.S. Processing of silicon tetrachloride formed during the production of semiconductor silicon. Moscow: Ekonomika, 1989, 49 p. (In Russ.)

5. Mitin V.V., Kokh A.A. The development of the market and the production technology of polycrystalline silicon. Izvestiya Vysshikh Uchebnykh Zavedenii. Materialy Elektronnoi Tekhniki = Materials of Electronics Engineering, 2017; 20(2): 99-106. (In Russ.). https:// doi.org/10.17073/1609-3577-2017-2-99-106

6. Photovoltaic Industry Price Trend: Polysilicon Sustains Minor Price Reduction While Large-Scale Products Remain Robust in Prices. https://www.energytrend.com/pricequotes/20201014-19600.html (accessed: 27.12.2021).

7. Polysilicon the key factor in 2020 PV industry supply as value-chain production forecast at $140 \mathrm{GW}$. https://www.pv-tech. org/editors-blog/polysilicon-the-key-factor-in-2020-pv-industrysupply-as-value-chain-production-forecast-at-140gw (accessed: 27.12.2021). and has not revived in the subsequent years despite multiple attempts all of which have unfortunately been absolutely feckless. Russia has finally gained auspicious conditions for the implementation of this ambitious and crucially important semiconductor industry project.

Of special importance is the choice of Siemens trichlorosilane process parameters. A specific feature of the Russian market is the presence of several very important fields (solar energy, microelectronics, high-power electronics, photonics and fiber optics) which are small by international standards and equally face raw material shortage. It appears that Russia will greatly benefit from integral projects delivering solutions of multiple raw materials supply problems.

\section{Acknowledgments}

The Authors are grateful to V.V. Ryazantsev for help in synthetic quartz technology description.

8. What's behind solar's polysilicon shortage - and why it's not getting better anytime soon. https://www.bernreuter.com/newsroom/pdf-articles/ (accessed: 27.12.2021).

9. TrendForce:Prices of Polysilicon Expected to Remain Sturdy on High Levels in 2021 under Balanced Supply and Demand. https:// www.energytrend.com/research/20210107-20605.html

10. Daqo polysilicon demand hit by 'dramatic rise' in ASPs. https:// www.pv-tech.org/news/daqos-polysilicon-demand-hit-by-dramaticrise-in-aspsShare (accessed: 27.12.2021).

11. Daqo begins pilot production at new polysilicon facility, targets 105,000MT of capacity by start of next year. https://www.pv-tech. org/daqo-begins-pilot-production-at-new-polysilicon-facilitytargets-105000mt-of-capacity-by-start-of-next-year/ (accessed: 27.12.2021).

12. Global and China Polysilicon Industry Report 2019-2023. https:// www.globenewswire.com/news-release/2019/05/24/1843135/0/en/ Global-and-China-Polysilicon-Industry-Report-2019-2023.html (accessed: 27.12.2021).

13 Xinyi Solar to enter polysilicon production with launch of new entity and Yunnan-based facility. https://www.pv-tech.org/xinyi-solar-to-enter-polysilicon-production-with-launch-of-new-entity-andyunnan-based-facility/ (accessed: 27.12.2021).

14. FBR polysilicon technology - promise or hype? http://www.bernreuter.com/en/references/library.html (accessed: 27.12.2021).

15. China's polysilicon output will reach 450,000 tons in 2020 . https:// www.funcmater.com/china-s-polysilicon-output-will-reach-450000-tons-in-2020.html (accessed: 24.02.2020).

16. PV Price Watch: Module prices stable as polysilicon prices continue downward trend. https://www.pv-tech.org/pv-price-watch-module-prices-stable-as-polysilicon-prices-continue-downward-trend/ (accessed: 27.12.2021). 
17. Fu R., James T.L., Woodhouse M. Economic measurements of polysilicon for the photovoltaic industry: market competition and manufacturing competitiveness. IEEE J. Photovoltaics, 2015; 5(2): 515-524. https://doi.org/10.1109/JPHOTOV.2014.2388076

18. Du Pont de Nemours: Divests Trichlorsilane Business and its Stare in Hemlock Semiconductor Join Venture. www.marketscreener.com /quote /stock/ (accessed: 09.09.2020).

19. Photovoltaic I: Polycrystalline Silicon. https://www.globalmarketmonitor.com (accessed: 27.12.2021).

20. Jarkin V.N., Kisarin O.A., Kritskaya T.V. Methods of trichlorosilane synthesis for polycrystalline silicon production. Izvestiya Vys- shikh Uchebnykh Zavedenii. Materialy Elektronnoi Tekhniki $=$ Materials of Electronics Engineering, 2021; 24(1): 5-26. (In Russ.). https://doi.org/10.17073/1609-3577-2021-1-5-26

21. Kritskaya T.V., Shvartsman L.Ya., Dodonov V.N., Kravtsov A.A. New Directions for Modernization of Semiconductor-Purity Silicon Technology. XIII Intern. conf. on topical issues of physics, materials science, technology and diagnostics of silicon, nanoscale structures and devices based on it ("Silicon-2020"). Yalta, 2020, p. 27. (In Russ.) 